\title{
Revisiting the Problem of Development the Tools on Effectiveness of Regional Economic Mechanisms
}

\author{
Maria A. Sinichkina* \\ Siberian Federal University \\ 79 Svobodny, Krasnoyarsk, 660041, Russia
}

Received 21.12.2014, received in revised form 04.02.2015, accepted 21.05.2015

The article studies the processes connected with the economic effects of globalization, which, in particular, is manifested in the need for redistribution of the powers of different branches of government in Russia. The author reveals the best management tools that guarantee a certain level of the regional economy efficiency. In addition, conceptual directions of specific industries reforming, as well as development of the mechanisms for the redistribution of power management power verticals are analyzed.

The author reasons the necessity for economic theory that could more adequately reflect the essence of modern processes in the Russian economy. The paper analyzes potential opportunities of economy in the context of globalization. The author studies theoretical aspects of the Russian economy development, which is heavily influenced by global trends. Development of a new economic theory which would represent the optimal combination of traditional and modern economic doctrines, according to the author's opinion, is a critical need for modern global science.

In the modern dynamic social-economic situation labor and education market is very volatile. A person should be able quickly orient in the changing environment and constantly choose from many alternatives that are the most suitable to him. The ability to choose consciously is one of the key skills of a modern man. This is what the majority of respondents, who in the future are going to work in their chosen specialty, believe.

The problem is that analysis of almost any socio-economic process or phenomenon requires an integrated approach from the social sciences, without any claims to universality of any single theory or science, and when studying the shadow economy the focus is quite often exclusively made on institutional and legal aspects, both the problem itself and its solution.

Economic development is accompanied by, and sometimes is produced by development of a subject and its activities, and major bifurcation points are accompanied by abrupt changes in its motivation as well as degree of specialization and ways of accommodation of interests.

In theory of stratification economic processes are revealed through such sociological categories as "person's social status", "social bonds", "interaction between individuals and groups", "group dynamics", "social behavior", "social exchange", etc.

As demonstrated in the article, economic criteria for assessing the status of the studied layers are ownership of productive property (capital), employment status, employment sector according to the form of property, social and sectorial employment, position in the management hierarchy and degree of well-being.

(c) Siberian Federal University. All rights reserved

* Corresponding author E-mail address: svb.704@yandex.ru 
It is well-known that economic efficiency is characterized by effectiveness of all the social production. From the standpoint of national economy, the state in which the needs of all the members of society are best met under conditions of limited resources is considered effective. Efficiency is determined not only through an increase in production figures, but also costs of the achieved growth, and their influence on social processes, particularly at the level of people's lives.

Keywords: regional economy, economic system, effectiveness of regional economies, management mechanisms, assessment of the effectiveness of power, "free market", ethno-economic systems, geoeconomic wars.

Research area: philosophy.

The necessity to develop national economic theory is determined by a complex of reasons, the main of which can be determined as follows. Firstly, socio-economic situation in Russia that has changed dramatically in recent decades has shown the failure of traditional approaches to the analysis of various internal problems of the country. Secondly, the ongoing reforms in scientific and educational spheres assume formation of large scientific schools, on the one hand, and training of economic theorists - on the other.

Risk society (U. Beck, N. Luhmann, A. Giddens) is understood as a special type of organization of modern societies with high levels of complexity and uncertainty of social processes and socio-cultural structures, caused by the spread of computer technology and achievements of post-book culture (Ustyantsev, 2009). Modern risk society is a world full of the paradoxes of post-industrial civilization nonlinear development (Kalashnikov, 2013), and Russia is a society of general risk (Yanitsky, 2014).

The head of the Saratov school of social riskology V.B. Ustyantsev, replacing the concept of "risk society" with the concept of "risk- taking society" in Russia, notes that the latter concept reflects the nature of risks as conditions of specific social situations (Ustyantsev, 2006). Russia is stable risk-taking territory, which generates "systemic risks". "Apparently, apocalyptics is also an important variant of risk institutionalization in the modern context. Since we are talking about the events of the "future" that did not become and do not necessarily follow our actions, apocalyptics gives an idea about an important parameter of the social world - its plasticity and dynamism out of cause-and-effect connections" (Doroshin, 2013).

Nowadays it is important for individuals to learn how to build dialogical relationship in order to identify and use effective and reasonable methods of reducing tension in society that contribute to increase in its tolerance and stability in the context of pluralism of interests, values, traditions, etc.

Striving for global thinking is common for creativity of Russian economists, but at the same time specifics of Russian Economic School with all its pluses and minuses was taken into account. One of the distinguishing features of the Russian school of social and economic thought was identification of education and culture along with the real wealth of moral factors as quality of life elements" (Chekmarev, 2012).

An important aspect of the aforementioned problem is that development of Russia is impossible without constant opposition and neutralization of the shadow component of economy. In this context the importance of an integrated multi-disciplinary approach to the analysis of shadow processes and to formation of a unified system to reduce their size, which basis should be formed by economic measures aimed at neutralizing the shadow economic interests is 
evident. The problem is that analysis of almost any socio-economic process or phenomenon requires an integrated approach from the social sciences, without any claims to universality of any single theory or science, and when studying the shadow economy the focus is quite often exclusively made on institutional and legal aspects, both the problem itself and its solution.

Another important aspect is that the basic for problem-oriented principles of correspondence of scientific and industrial purposes to scientific and technical potential as the evaluative one is does not work in private corporations. This is connected to the fact that it is usually implemented in practice by changing scientific and technical staff, but here problems arise for corporations, connected with fundamental characteristics of innovation system and, therefore, can be solved neither in the field of higher and technical education, even if it is financed by corporations "for themselves", nor at the corporate level (Bogatova, 2009).

Thus, social need for the development of a new economic policy is determined by intensification of globalization processes in the modern world, and the Russian Federation is involved in them. Nevertheless, Russian scientists should mostly take into account domestic experience of management and revive the unique theoretical works of Russian thinkers, for example, A.A. Bogdanov's tectology.

Russian thinkers of the late $19^{\text {th }}$ and early $20^{\text {th }}$ century quite often raised the issue of technological developments ambiguity and the negative consequences of a process that today is called "globalization". People and countries got closer, transport infrastructure and other means of communication were developing, but this rapprochement separated them more - both people and countries. Much of the seemingly stable, eternal and timeless was becoming more and more illusory.
There is a direct dependence, the stronger and more independent Russia is, the tougher is pressure from the West. Russia claimed to be the world, rather than regional state, but after the disaster of the $90^{\text {th }}$ nobody in the West was going to admit it without serious struggle. It can not be otherwise: the balance between the major centers of power is formed on the basis of the power of each of them, and no one will ever become indifferent observing the growth of their competitor's power. Stop it and keep the competitor under control is natural and understandable desire.

The majority of Russians, their intentions, mentality, goals and ideals are unintelligible for the West, and no one tries to comprehend them. But it was an appeal to the majority that allowed Putin proclaim conservatism as ideological doctrine, and steadily adhere to nationally oriented positions in external policy, trying, as far as possible, to position Russia as an equal partner of the West.

Famous futurist A. Toffler, in particular, writes about the necessity to develop unconventional approaches to the modern science in general and economic on particular: “... New technologies require making changes in equipment; they suggest new solutions to social, philosophical, and even personal problems. They change all the intellectual environment of man and his world" (Toffler, 2002). He is echoed by A. Giddens, who emphasized that "... the forms of life, created by modernity, rended us from the traditional types and did it in an unprecedented way" (Giddens, 2011).

In the modern dynamic social and economic situation labor and education market is very volatile. A person should be able to orient quickly in the changing environment and constantly choose from a lot of alternatives the one that is the most suitable to him. The ability to choose consciously is one of the key skills of a modern man. This is what the majority of respondents, 
who in the future are going to work in their chosen specialty, believe.

On this way past experience should not be ignored and achievements of the Western scholars should not be blindly copied, since:

- modern Western economic science is characterized by a multiplicity of approaches and ideas;

- Western economic science has certain contradictions;

- major methodological problems are not developed within the frames of traditional modern science;

- economic science of modern Europe has weak social orientation;

- in many cases, a separate economic phenomenon is formalized as a law or a rule.

In addition, economic science of the modern Europe and the United States is largely formalized as presentation of theoretical provisions is overloaded with graphs and mathematical formulas. "Such an abundance of mathematics raises the risk of degeneration of economic theory as an integral and systematic fundamental science" (Chekmarev, 2012).

If we try to summarize the situation that aroused in the modern economic science, we have to admit that it can not adequately express the essence of the contradictory social and economic processes that take place in our country. "The huge gap that took place in relations between reality that is expressed in scale and high rate of change in technologies, reorganization and establishment of new social institutions, and comprehension of this gap has become so great that social and cognitive paradigm, with its methodological procedures in scientific researches is brought to the forefront by time" (Kalashnikov, 2013).

If we raise an issue of the need to renew economic theory, the problem of alienation that is understood in the broadest sense, i.e. as deprivation of the dominant part of population the possibility to control the wealth of country, appears to be of high priority. This problem has ancient roots, for example, for Aristotle alienation had quite a specific character: "it is connected to the functioning of state as "communication of free people" united in self-sufficient whole, and means exclusion or transfer of property from the whole, which has to be common only in a relative sense, and in general it has to be private" (Kal'noi, 1990).

Major review of human cognitive capabilities and orientation to optimize activity, both in society and in relation to nature are of fundamental importance as well. It is important to note that a variety of categorical meanings that are attributed to the modern ideas about the economy, evidence about universal, multifaceted, all-encompassing image that appears to the person of the economic world. That is why the study and, especially, development of a new economic policy requires special methodology for formation of the theoretical foundations of this, in fact, holistic worldview (Miakinnikov, 2013).

The urgent need for a new economic theory is quite clearly evidenced on the example of a sector that defines the full potential of a state, as energetics. Development of industry and renewable energy sources and urban growth has greatly increased the requirements for energy and information security, flexibility and reliability of network. The level of technological and informational integration of energy systems of the late $20^{\text {th }}$ century could not respond to new challenges. The energy complex of our country is nowadays in a sad condition: the equipment of worn out by more than $50 \%$; about $60 \%$ of power lines need rerouting. Due to power lines deterioration energy losses reach 20-30 \%, instead of 6-8 \% (energy loss in Europe), and disruptions in energy supply happen more often. The main reasons lie not only in the high level of 
moral and physical depreciation of fixed assets of energy companies, but also in the technical level, reliability, cost effectiveness and fuel efficiency.

Large-scale modernization with the use of "smart grids" is necessary. The term itself started to be used in 1998, although studying the possibilities of creating and implementing such technologies were conducted in Europe, the USA and the USSR as early as in the 70s.At that period, first of all, it referred to self-diagnosis, and the main task was to improve the reliability of the equipment and possibility of its remote control (Naumova and Osipova, 2013).

Nowadays, the term "smart grids" has acquired a broader meaning and announced itself as a new large-scale direction in energetics, that allows, on the one hand, to solve the problems related to energy efficiency - reduce energy losses, and annually in the world from $5 \%$ to $15 \%$ of energy is lost in the process of energy transfer, to reduce resources costs and emissions into the atmosphere. On the other hand, make the life of modern man more comfortable, for example, control power supply and home electronics in a house with the use of these technologies.

The epoch of dual, contradictory policies, when Western countries played a role of halfpartners - half-rivals of Moscow is over. Russia has a clear, understandable for everyone image. And though it is perceived as hostile in the West, it is in great demand in the East. The Russian model is becoming a real alternative to the American conception of controlled chaos. It is not a coincidence that nowadays some political analysts speak about the return of Moscow to the region that over the last decade has been the main field for the American experiment.

Abstract alienated labor has the right to power, but it can not exercise this right itself. For this special historical subject with power, if not dictatorial, then, at least, monarchical and aristocratic, serves on behalf of labor. Only in the process of the liberation of labor and overcoming its alienation real political rights of each individual that come directly from its victims should appear. Overcoming alienation of labor does not mean disappearance of the phenomenon of labor as absorption of life by activities. Inclusion of man into activity, even fully perceived by man himself, carried out exclusively by the decision of man, does not negate the fact that activity absorbs his life (Sergeitsev, 2014).

For conventionalists, high values can not be given for nothing, but they are the result of the importance of personality, it can also be applied to "freedom", "merits" (i.e. special rights), not to mention "honor". Real conventionalist reasons from the fact that these high ideals can not be handed out as promotional booklets or labels, for example, the status of "freedom" implies that a person corresponds to it, that "freedom", i.e. individual's sovereignty has a basis. Otherwise, if a conventionalists flirts with democratic interpretation of rights and freedoms, he refuses his essence and he is not a true conventionalists. Completefreedomisconnected withcreativity, and therefore, by definition, is aristocratic. Therefore, positive meaning of liberation of personality lies not in general availability of social freedom, but in provoking creative boom, revival of active creative and healing powers among people. Any other liberation gives only a parody of freedomsovereignty, legitimizes licentiousness and dullness, security and mediocrity. Such freedom is simply meaningless.

A fundamental anthropological mistake the wrong idea about the nature of man lies at the root of this false liberation. An emancipated individual, who left all the obligations to people, family, history and social environment is not free, but devastated man. He threw away not external chains, but parts of his own inner world, distorted holistic worldview, cutting the significant fragments from it. Freedom of private life does 
not protect human personality from suppressing influence of extraneous will. Today, in the era of the latest Twitter revolutions, this focus with "individual liberty" is self-disclosed and becomes clear not only for inveterate conventionalist, but for any conscientious observer.

The next stage of "progress" goes behind the values of freedom: equality and "democracy" as average, willingness and desire to be "like everyone else" and equate everybody to low medium level. If at the first stage of lowering transformation the world of money and quantity simply ignored the "higher", at the second stage dictate of "average man" begins (Averianov, 2014).

Study of the essence of modern economic space suggests considering economic centrism as a defining trend of our time, what is connected with the following circumstances.

1. Significant and continuous increase of the role of economics in the life of society has led to economic centrist view at the whole system of social relations.

2. Sequential reduction and weakening of regulatory functions that traditionally were prerogative of state and contributed to chaotization of economic space.

3. Formation of economic space based on the new principles has resulted in acquisition of new quality that requires organization of a new economic, political and legal system, which gradually acquires global status and starts functioning as a single global entity.

4. Formation of qualitatively new and relatively newly established social institutions, structures and entities that in varying degrees are responses to new economic global-regional realities.

Modern economic space has the following features.

Firstly, the answer to the question about the nature of economic space, as a rule, is searched in the field of economic relations of the modern society, built upon western theories.

Secondly, adequate understanding of the nature of modern economic space is impossible without understanding dynamics of the historical processes that preceded it.

Thirdly, economic relations are affected by other social relations, for example those, emerging in the region, related, in particular, to the terms of people's production activities that fundamentally affects formation of an appropriate economic space.

Economic development is accompanied by, and sometimes produced by development of a subject and its activities and major bifurcation points are accompanied by sharp changes in the field of its motivation, as well as degree of specialization and ways of reconciliation of interests.

Economic processes in the theory of stratification are revealed through such sociological categories as "social status of personality", "social connections", "interaction between individuals and groups", "group dynamics", "social behavior", "social exchange", etc.

Economic criteria for assessing the status of the studied layers are ownership of productive property (capital), employment status, employment sector according to the form of property, social and sectoral field of employment, position in management hierarchy and degree of well-being.

It is known that economic efficiency is characterized by effectiveness of social production. From the standpoint of national economy, the state in which the needs of all the members of society under conditions of objectively given limited resources are best met is considered effective. Efficiency is determined not only by increase in production figures, but costs, by means of which the achieved gains are 
provided, and their influence on social processes, especially at the level of people's lives.

Cost-effectiveness is relative number, it will approach to the absolute depending on how it will correspond with social efficiency, which is identified by the level and quality of life of the majority of population.

According to economic laws, pace, direction and type of the national economy development depends on its past, including structures and mechanism of its operation, the achieved level of development, the nature of environment and the type of bonds. The past of national economy is a certain "restrainer" when it chooses an attractor at the bifurcation point: out of numerous ways of development it can choose only those that are appropriate to its nature and the level of development formed in the course of its past development, i.e. economy develops in accordance with the principle of continuity, the picture changes involuntarily, but each following moment is agreed to the previous state.

Study of such a complex and ambiguous category as "economic space" supposes appeal to classical works. It is known that Adam Smith in his book "An Inquiry into the Nature and Causes of the Wealth of Nations" was one of the first who thoroughly developed the nature of economy based on the example of bourgeois economic system. A. Smith is one of the authors of the theory, according to which labour is the essence of any cost. Thus, he revealed socio-economic basis of labor in society. A. Smith justified division of productive and nonproductive labor. He believed that division of labor is an important factor for economic development as it expanded the use of machinery. As he saw limited impact of division of labor on man, he offered to compensate it by introduction of universal education. A. Smith divided society into three classes: wage workers, capitalists and large landowners, considering this division natural. According to him, the main source of social wealth is individual pursuit to well-being, and desire to achieve a high position in society. He regarded domination of private property, non-interference of state into economics and absence of obstacles for private initiative as conditions for society prosperity. A. Smith recognized the objective nature of economic laws, used materialist methodology of economics analysis, thus contributing to the study of such a phenomenon as economic space.

G. Hegel identified labour with activity in general, including a wide range of activities into labour: theoretical work, work for the production of goods, work for the sake of common interests, such as state and creative ones (artistic activity and fulfilling the functions of faith). In connection with labour G. Hegel considered a lot of related problems, means of labor, objects of labor, property, etc. G. Hegel's legacy in the field of philosophical problems of labor has not truly been understood and appreciated yet.

Max Weber paid great attention to social and philosophical issues of economics and economic sociology. He considered economic life as an integral part of society that is closely connected to its other parts and especially to politics, law and religion. In the course of social phenomena analysis M. Weber methodologically proceeded from the concept of the ideal type that represents reality in logical consistency and rational accuracy. M. Weber identified two ideal-typical orientations of economic behavior: the traditional and the purposeful rational ones. The main idea of M. Weber's economic sociology is the idea of economic rationality, which allows achieving economic efficiency and optimal behavior in the economic sphere. From the standpoint of purposeful rational action Weber gave a comprehensive analysis of the capitalist society economics. Particular attention was paid to the relationship of ethical code of the Protestant denominations 
and the spirit of the capitalist economic and lifestyle ("The Protestant Ethics and the Spirit of Capitalism”, 1904-1905) and Protestantism stimulated formation of the capitalist economy. $\mathrm{He}$ also studied the connection of rational law and management economics. Weber proposed the idea of rational bureaucracy that represents the highest embodiment of capitalist rationality ("Economy and Society", 1921). M. Weber argued with K. Marx, believing that it was impossible to build socialism.

S.N. Bulgakov strongly defends relevance of the philosophical system that considers the world as household. In his opinion the basic question of philosophy of household is "whether there is a man, a thing or an object which interpretation should be searched in the impersonal, also objective world of things, and the mechanism of things that defines business process, or, conversely, the latter is explained from the nature of economic subject, generated by its activities, imprinted by its subjectivity". Answering this question, S.N. Bulgakov gives priority to a subject which he understood as universal (transcendental) subject, humanity as a whole, a living unity of spiritual forces and potencies, in which all the people are involved, an intelligible man who is empirically detected in separate personalities. Labour itself and housekeeping was understood by S.N. Bulgakov as creative activity of intelligent beings, the basis of which is freedom as creativity. Culture is created in household, it is permeated by spirituality as a defining moment. In this connection S.N. Bulgakov profoundly raised the question of science and household as manifestations of science. In general, the problem of household for him was the edge of the problem of meaning of life. Statement of many philosophical problems of economic life, reference to the views of prominent philosophers, especially F. Schelling, interesting polemic with K. Marx even today make the book by S.N. Bulgakov an important phenomenon of the philosophy of economics of the $20^{\text {th }}$ century. (Bulgakov, 1990).

We can conclude that all the great philosophers and economists admitted that solution of many material problems depends both on the specific economic reality and methodology of its study. However, supporters of anthropocentric economy has always been in minority, and in public consciousness the idea that economy is a field in which the main motivation of people and organizations is to maximize their profits, regardless of what kind of people and organizations these are, what country they are located in and what are their world views has clearly strengthened.

Nevertheless, mechanisms described by economists are not always implemented in real life situations. The very structure of human psyche greatly prevents rational decision-making. Thus, back in the $60 \mathrm{~s}$ of the $19^{\text {th }}$ century psychologists found evidence of surprisingly powerful influence of situations upon people's actions.

In the study of economic space it is important to keep to the following methodological principles of social dialectics:

- to find contradictions that are the source of development of the studied economic phenomena and processes.

- To identify causative and regular relations of their development (the principle of social determinism).

- To reason from the fact that any social phenomena laws of development, including economic ones, function not with mathematical precision, but rather as tendencies for these phenomena development, and are largely of probabilistic nature.

- To consider content and direction of activity of the subjects of socio-economic processes and their influence upon these 
processes, in accordance with their interests.

Historical analogy plays an important role in the study of economic space. For example, many researchers compared history of capitalism development in the UK - one of the first European capitalist countries to the history of capitalism development in France, Germany, the United States and other countries. It was documented that in these countries, as well as in the UK, economy developed from free competition of small and medium-sized industrial, commercial and financial enterprises to domination of the later formed industrial, commercial and financial monopolies. On this basis, it was concluded that other properties of the economy of France, Germany and the United States are similar to the UK economy.

So-called cause and effect models are used when studying economic space. They help to identify objective cause and effect relationships and interdependencies between economic phenomena, generation of some of them by others, as well as emergence of their new properties. However, these models do not always allow to draw conclusions about the studied phenomenon in general, as revealing its objective aspects, they do not trace subjective factors that regard minds of people, whose actions determine the content and focus of any social phenomena and processes. This difficulty is resolved by economists in the following way: in the course of analysis of the processes that take place in the whole society, i.e. at the macro level, cause and effect models, revealing objective factors of people's activity and behavior are used, and in the course of analysis of the processes that take place in separate regions, i.e. at the micro level, cognitive models of interaction between small systems are used along with the cause and effect models with which help motives, beliefs and goals of economic operators are identified.
While studying economic space, models of wave dynamics that reproduce undulating nature of economy, depending on economic conditions, are used. Famous Russian scientist N.D. Kondrat'ev gave scientific credence to the idea of such development of economics, that, in particular, revealed the existence of "long waves" in its development, depending on mass introduction of new equipment and technologies into production, structural changes connected to emergence of new sectors of economy, as well as various political factors and social unrests (Kondrat'ev, 1989).

System approach is based upon principle of systematics, and theory of self-organization upon principle of development. Both two principles complement each other and form a unity that is reflected in cognition. Unity of theory of self-organization and systematic research is reflected in the fact that the first is based upon methodology and theoretical conclusions of the second. Synergetics, theory of change and catastrophe theory refer to the theories of selforganization.

For socio-economic systems this condition is characterized by transition to the critical ratio of cost of labour, materials, energy and raw materials required for the expansion of goods production and to maintain the state of simple reproduction of the means of production. From that moment major disjoint of functional relationships between all the elements of socio-economic system begins. Such process development can be called a self-developing chaos.

All this explains why the countries of agricultural and primary sector, or those, in the early stages of industrialization are in the least favorable position, and most part of multinational companies concentrate their efforts on the development of global markets of high-tech products in by reducing their presence in the 
lower "levels" of production and trade (Shishkov, 2005).

Institutional approach to defining the parameters of economic development includes not only traditional indicators that determine status and development of natural-climatic and geographical potentials, materialized capital (quantity and quality of land, volume, structure, status and effectiveness of fixed assets, etc.) and financial capital, but non-materialized capital as well (intellectual property, information), scientific potential, market environment (competition level, market infrastructure, etc.), global factors and conditions (the state of the world economy, globalization of economy, external threats, etc.).

According to V.G. Lebedev, business sphere is connected to the process of productive forces development, scientific and technological revolution and transformation of social production relations. V.G. Lebedev writes: "Accordingly to the nature of this potential it should be presented, first of all, as an increase in mass and composition of traditional material and spiritual benefits; volume and structure of the new consumer values; speed and scale of their renewal; an increase in free time as a result of growth in labor productivity; decrease in production costs due to introduction of scientific and technological achievements; qualitative improvement of working and living conditions; creation of material background for creative activity; increase in the degree of socialization of production as a condition for development of socialist collectivism, improvement of production skills and education of workers" (Lebedev, 2007).

For the objective study of economic space different methodological basis, namely dialectic one, is required. Theorizing regional economy in the global context, in particular, implies objective dialectics of social processes. Under conditions of universal connection of phenomena, the process of objective dialectics is ambivalent and comprises the unity of time series and direction of anti-entropic processes that give them orientation. Tectological whole of objective dialectics assumes existence of its extreme points that separate tectology from technology. They characterize the whole as bigger or less than the sum of parts, or a part that is bigger than the whole. Tectological whole does not include technological whole which is equal to the sum of its parts.

Economic space is fundamentally dependent on the territorial behavior and is an important attribute of human social behavior, implicitly comprising territory into the subject-object relationship. Thanks to the unique coincidence and intertwining of factors that are integrated in each given territory, over the centuries stable territorial behavioral patterns that up to the present moment significantly influence people's behavior were formed. It is possible to agree with the following statement: "In a global world Russia faced a dilemma: either to find a way to overcome irresponsible consumer morale, or finally sink into the abyss of geopolitical chaos and slippage into the "third world"" (Yatsenko and Malinin, 2012).

Different models of economic space appear due to natural and climatic characteristics of different territories and territorial division of labour; that is why analysis of the territorial economic situation plays the most important role for science and social practice. At different levels of generalization, in different historical periods, we find different levels of territorial division of labor and the corresponding levels of regional economics that are closely entwined, but selfsufficient. Analysis of these levels, as well as specific forms of economic space, characteristic for certain regions of the world, gives an opportunity to get closer to understanding the causes of many problems of the modern global society. 
Thus, development of the instrumentarium to assess the effectiveness of regional economic mechanisms implies a special methodological apparatus that should take into account characteristics of regional economy, since, according to economic laws, the speed, direction and type of the national economy development depends on its past, including structures and mechanism of its functioning, reached level of development, the nature of environment and the type of bonds.

\section{References}

1. Averianov V. Sokrytaia charisma [Hidden Charisma] // Odnako. April-May 2014. (173). P. 174.

2. Bogatova E.V. Metodologicheskie voprosy izucheniia innovatsionnogo processa $\mathrm{v}$ real'nom sektore ekonomiki [Methodological Issues of the Innovative Process Studying in Real Sector of Economics] // News Bulletin of Herzen State Pedagogical University of Russia. 2009. № 111. P. 53.

3. Bulgakov S. Pholosophiia khoziaistva [Philosophy of Household]. Part. 1. The World as Household. M: Mauka, 1990.

4. Giddens A. Posledstviia sovremennosti [The Consequences of Modernity]. M., 2011. P. 115.

5. Doroshin I.A. Apokalipticheskiie ozhidaniia v obshchestve riska [Apocalyptic Expectations in the Society of Risk] // Bulletin of Chelyabinsk State University. 2013. №33 (324). P. 100.

6. Zamaraeva Yu.S. Osobennosti etnicheskoi migratsii v sotsial'no-psikhicheskom vospriatii (na materiale analiza resul'tatov eksperimenta po metodike "Seriinye tematicheskie assosiatsii”) [Special Aspects of Ethnic Migration in Social and Psychological Comprehension (Exemplified by Analysis of the Experiment Results on the Methods of "Serial Thematic Associations")] // NB: Problems of Politics and Society. 2014. № 9. Pp. 63-82. DOI: 10.7256/2306-0158.2014.9.13407. URL: http://e-notabene.ru/ pr/article_13407.html

7. Il'beikina M.I. Nekotorye aspekty teorii sotsial'nykh tsennostei [Some Aspects of The Social Values Theory] // Sociodynamics. 2014. № 12. Pp.78-89. DOI: 10.7256/2409-7144.2014.12.13901. URL: http://e-notabene.ru/pr/article_13901.html

8. Kalashnikova E.M. Istoricheskie i metodologicheskie osnovaniia identifikatsii i identichnosti $\mathrm{v}$ usloviiah "pozdnei sovremennosti" [Historical and Methodological Foundations of Identification and Identity Study under Conditions of "Late Modernity"] // Bulletin of Chelyabinsk State University. 2013. №33 (324). Philosophy. Sociology. Culturology. Issue. 30. P. 35.

9. Kal'noi I.I. Otchuzdenie: istoki i sovremennost' [Subtraction: Origins and Modernity]. Simferopol: Tavriia, 1990. P. 9.

10. Kara-Murza S.G. Katasrofy, khaos, razvitie [Catastrophes, Chaos, Development]. M.: Smis, 1998. P. 41.

11. Kirko V.I., Bukharov A.V., Keush A.V. Otsenka innovatsionnogo potentsiala tipovykh territorial'no-administrativnykh obrazovanii Krasnoiarskogo kraia [Evaluation of Innovative Potential of the Typical Territorial and Administrative Units of Krasnoyarsk Krai] // Innovations. 2010. № 12. Pp. 78-83.

12. Kistova A.V. Formirovanie kommunikativnogo (interpritativnogo) etnographicheskogo etnographicheskogo metoda $\mathrm{v}$ sovremennom sotsial'nom poznanii [Formation of Communicative (Interpretative) Ethnographic Method in the Modern Social Cognition] // NB: Problems of Politics and 
Society. 2014. № 11. Pp.62-72. DOI: 10.7256/2306-0158.2014.11.1352. URL: http://e-notabene.ru/pr/ article_13527.html

13. Kovtun N.V. Patriarkhal'nyi mif $\mathrm{v}$ traditsionalistskoi proze rubezha XX-XXI vekov [Patriarchal Myth in Traditionalist Prose of the Turn of the $20^{\text {th }}-21^{\text {st }}$ Centuries] // Siberian Philological Journal. 2013. № 1. Pp. 77-87.

14. Kondratiev N.D. Problemy ekonomicheskoi dinamiki [Problems of Economic Dynamics]. M., 1989.

15. Kondratiev E.A. Tenevye protsessy: problem metodologii [Shadow Processes: Problems of Methodology] // Bulletin of Orlov State University. Ser.: New Humanitarian Research. 2011. № 5 (11). P. 195.

16. Kolesnik M.A. Sotsiologicheskie issledovaniia voobrazheniia v 30 -e 80 -e gg. XX veka [Sociological Researches of Imagination in the 30s 80s of the $20^{\text {th }}$ Century]. 2014. № 11. Pp. 45-61. DOI: 10.7256/2306-0158.2014.11.1351. URL: http://e-notabene.ru/pr/article_13517.html

17. Kopseva N.P., Karlova O.A., Moskvich Y.N. Rezkova K.V., Semenova A.A, Pimenova N.N., Kistova A.V., Sertakova E.A. et al. Novoe budushchee Sibiri: ozhidaniia, visovy, resheniia [New Future of Siberia: Expectations, Challenges, Solutions]. Krasnoyarsk, 2013.

18. Lebedev V.G. Proizvoditel'nye sily I sotsial'nyi progress [Productive Forces and Social Progress]. M.: Kniga i Biznes, 2007. Pp. 172-178.

19. Luzan V.S. K probleme kontseptual'nykh osnovanii politiki [To the Problem of Conceptual Foundations of Cultural Politics]. 2014. № 10. Pp. 135-158. DOI: 10.7256/2306-0158.2014.10.1342. URL: http://e-notabene.ru/pr/article_13420.html

20. Miakinnikov S.P. Osnovnye aspekty erkhitektroniki mirivozzreniia kak sotsial'nogo fenomena [The Basic Aspects of World View Architectronics as a Social Phenomenon] // Bulletin of Chelyabinsk State University. 2013. №33(324). Philosophy. Sociology. Culturology. Iss. 30. P. 8.

21. Naumova T.A., Osipova I.M. Tekushchee sostoyanie vnedreniia innovatsionnikh tekhnologii smart grid v energeticheskom komplekse RF [The Current State of Smart Grid Innovative Technology Implementation in Energy Complex of the Russian Federation] // Bulletin of Irkutsk State Technical University. 2013. №1. P. 171.

22. Pimenova N.N. Korennye malochislennye narody v sovremennoi situatsii: ob'em i soderzhanie poniatia [Small Indigenous Peoples in the Modern Situation: Scope and Content of the Notion] // Sociodynamics. 2015. № 1. P. 112-134. DOI: 10.7256/2409-7144.2015.1.14249. URL: http://e-notabene. ru/pr/article_14249.html

23. Razumovskaya V.A. Izomorphism poeticheskogo teksta $v$ aspektakh poetiki i perevoda [Isomorphism of the Poetic Text in the Aspects of Poetics and Translation] // Journal of Krasnoyarsk State University. Humanities. 2006. № 6-2.- Pp. 55-59.

24. Reznikova K.V. K voprosu ob utochnenii poniatii "etnos" i "etnichnost" [Revisiting Specifications of the Concepts of "Ethnos" and "Ethnicity”] // Sociodynamics. 2014. № 12. Pp. 90102. DOI: 10.7256/2409-7144.2014.12.13913. URL: http://e-notabene.ru/pr/article_13913.html

25. Reznikova K.V., Koptseva N.P. Metodologicheskie vozmozhnosti antropologicheskoi shkoly "Kul'tura-i-lichnost" dlia sovremennikh rossiiskikh sotsial'no-kul'turnykh issledovanii [Methodological Possibilities of Anthropological School "Culture-and-Personality" for Modern Russian Socio-Cultural Research] // Modern Problems of Science and Education.- 2013. № 4. P. 388. 
26. Sergeitsev T.K. K sotciologii russkogo postsotsializma [To the Sociology of Russian PostSocialism] // Odnako. April-May 2014. (173). P. 45.

27. Seredkina N.N. Et nicheskaia kartina mira $v$ konterste sovremennykh sotsial'nikh issledovanii [Ethnic Picture of the World in the Context of the Modern Social Research] // NB: Problems of Politics and Society. 2014. № 10. Pp. 26-59. DOI: 10.7256/2306-0158.2014.10.1344. URL: http://e-notabene.ru/ pr/article_13441.html

28. Sitnikov A.A. Sovremennye praktiki forsait-issledovaniia budushchego sotcial'noantropologicheskikh sistem, $\mathrm{v}$ tom chisle etnokul'turnykh severnykh regionov Rossiiskoi Federatsii [Modern Practices of Foresight-Research of the Future of Social-Anthropological Systems, Including Ethnic Cultural Groups of Northern Regions of the Russian Federation] // NB: Problems of Politics and Society. 2014. № 9. Pp. 44-62. DOI: 10.7256/2306-0158.2014.9.13405. URL: http://e-notabene.ru/ pr/article_13405.html

29. Toffler A. Shok budushego [Future Shock]. M., 2002. P. 42.

30. Ustyantsev V.B. Predmet, kategorial'nye riady i kontseptsii sotsial'noi riskologii [Subject, Categorical Range and Conceptions of Social Riskology] // Society of Risk: Management Strategies and Alternative Styles of Thinking / edited by V.B. Ustyantsev, M.O. Orlova. Saratov: Nauka, 2009. P. 14.

31. Ustyantsev V.B. Chelovek, zhiznennoe prostranstvo, riski: tsennostnyi i institutsional'nyi aspekty [Man, Life Space, Risks: Axiological and Institutional Aspects]. Saratov: Saratov State University Publishing House, 2006.

32. Chekmarev V.V. Rossiiskaya shkola sotsial'no-ekonomicheskoi mysli I puti ee razvitiia (po materialam mezhdunarodnoi nauchnoi konferentsii "Ekonomicheskie instituty sovremennoi Possii") [Russian School of Social-Economic Thought and Ways of its Development (Following International Scientific Conference "Economic Institutes of Modern Russia")] // University Bulletin. SPb. 2012. № 2. Pp. 193-194.

33. Shishatskii N.G., Kirko V.I., Keush A.V. Sotsial'no-ekonomicheskie problemy sozdaniia territorii traditsionnogo prirodopol'zovaniia [Social and Economic Problems of Creation of the Territories of Traditional Use of Natural Resources] // Arctic and the North. 2012. № 7. Pp. 178184.

34. Shishkov Y. Evolutsiia mirovogo ekonomicheskogo prostranstva [Evolution of the World Economic Space] / Y. Shishkov. M., 2005. P. 180-181.

35. Yanitsky O.N. Rossiia kak obshchestvo vseobshchego riska [Russia as a Society of Universal Risk] [Electronic Source] URL : ecsocman.lise.ru/data / 853/685/1219/019 yanit skij.pdf

36. Yatsenko M.P., Malinin A.V. Problema sovershenstva v kontseptsiiakh russkogo kosmizma [The Problem of Perfection in Conceptions of Russian Cosmism] // Scientific Opinion: Scientific Journal. SPb., 2012. №12. P. 22.

37. Kistova A.V., Pimenova N.N., Zamaraeva Ju.S., Reznikova K.V. Research possibilities for studying the indicators of quality of life of indigenous peoples of the North (based on the study of indigenous peoples of the North of Russia). Life Sci J 2014; 11(6s):593-600.

38. Koptseva N.P. Indigenous peoples of Northern Siberia (Krasnoyarsk Krai, Russia): current problems // AYER . 2014. №1. Pp. 55-74.

39. Koptseva N.P., Kirko V.I. Ethic identification of indigenous people of the Siberian Arctic / Koptseva N.P., Kirko V.I. // American Journal of Applied Sciences. 2014. Vol. 11. № 9. Pp. 1573-1577. 
40. Koptseva N.P., Kirko V.I. Specificity of ethnogeny indigenous peoples by central Siberia in the transition from the traditional type of society to modern society // Life Science Journal, 2014. Vol. 11. № 8. Pp. 221-229.

41. Koptseva N.P., Kirko V.I. The information basis for formation of positive ethnic identities in the process of acculturation of indigenous peoples of the arctic Siberia (Krasnoyarsk, Russia) // Life Science Journal, 2014. Vol. 11. № 8. Pp. 479-483.

42. Koptseva N.P., Kirko V.I. Processes of Acculturation Khakases (Indigenous People of Southern Siberia), Living Outside of the Khakassia in the Urbanand Student Environmen // American Journal of Applied Sciences 2014, 11 (12): 1969-1975 DOI: 10.3844/ajassp.2014.1969.1975

43. Libakova N.M., Sitnikova A.A., Sertakova E.A., Kolesnik M.A., Ilbeykina M.I. Interaction of the Yakut ethnicity and biological systems in the territory of the Sakha Republic (Hordogoy Settlement, Suntarsky District) and Krasnoyarsk Krai (Essey settlement, Evenks District). Life Sci J 2014; 11 (6s):585-592.

44. Libakova N.M., Sitnikova A.A., Sertakova E.A., Kolesnik M.A., Ilbeykina M.I. Modern practices of regional and ethnic identity of the Yakuts (North Asia, Russia). Life Sci J 2014; 11(12):133140 .

45. Reznikova K.V., Zamaraeva J.S., Kistova A.V., Pimenova N.N. The current state of traditional socio-cultural practices of indigenous peoples of the North (on the example of cultures of Selkups, Nenets and Essey Yakuts). Life Sci J 2014; 11(12):126-132.

\section{К проблеме разработки инструментов по оценке эффективности региональных экономических механизмов}

М.А. Синичкина Сибирский федеральный университет Россия, 660041, Красноярск, пр. Свободный, 79

\begin{tabular}{l}
\hline В статье исследуются процессы, связанные с экономическими эффектами глобализации, \\
которая, в частности, проявляется в необходимости перераспределения полномочий \\
различных ветвей власти в России. Автор раскрывает оптимальный управленческий \\
инструментарий, которыйгарантируетопределенныйуровеньэффективностирегиональной \\
экономики. Кроме того, анализируются принципиальные направления реформирования \\
конкретных отраслей, а также выработка механизмов перераспределения управленческих \\
вертикалей власти. \\
Автор аргументирует необходимость выработки экономической теории, которая более \\
адекватно отражала бы сущность современных процессов в экономике России. В статье \\
анализируются потенииальные возможности экономики в условиях глобализаиии. Автор \\
исследует теоретические аспекть развития российской экономики, которая находится под \\
серьезным влиянием мировых тендениий. Выработка новой экономической теории, которая \\
представляла бы собой оптимальное сочетание традицинных экономических и современных \\
учений, по мнению автора, является насущной потребностью современной глобальной науки. \\
В современной динамической соииально-экономической ситуации очень изменчив рынок
\end{tabular} 
труда и образования. Человеку необходимо уметь быстро ориентироваться в изменяющихся условиях и постоянно выбирать из множества альтернатив наиболее подходящие именно ему. Умение выбирать осознанно - одно из ключевых умений современного человека. Так считают большинство опрошенных, которые в будущем собираются работать по выбранной ими специальности.

Проблема состоит в том, что анализ практически любого социально-экономического процесса или явления требует от общественных наук комплексного подхода, без претензий на универсальность какой-либо одной теории или науки, а при исследовании теневой экономики достаточно часто акцент делается исключительно на институционально-правовой аспект как самой проблемы, так и ее решения.

Экономическое развитие сопровождается и иногда продуцируется развитием субъекта, его деятельности, а крупные точки бифуркации сопровождаются резкими изменениями в сфере его мотивации, а также степени спеииализации, способах согласования интересов.

Экономические процессы в теории стратификаиии раскрываются через такие социологические категории, как «сочиальный статус личности», «социальные связи», «взаимодействия между индивидами и группами», «групповая динамика», «социальное поведение», «соииальный обмен»и др.

Как показано в статье, экономическими критериями оценки статуса изучаемых слоев являются владение производительной собственностью (капиталом), статус занятости, сектор занятости по форме собственности, социально-отраслевая сфера занятости, место в управленческой иерархии, ступень благосостояния.

Экономическая эффективность, как известно, характеризуется результативностью всего общественного производства. С точки зрения наииональной экономики эффрективным признано такое состояние, при котором наиболее полно удовлетворены потребности всех членов общества при объективно заданных ограниченных ресурсах. Эффективность определяется не только приростом показателей производства, но и затратами, за счет которых обеспечены достигнутые приросты, и их влиянием на социальные процессы, прежде всего на уровень жизни людей.

Ключевые слова: региональная экономика, экономическая система. эффективность региональных экономик, управленческие механизмы, оценка эффективности власти, «свободный рынок», этноэкономические системы, геоэкономические войны.

Научная специальность: 09.00.00 - философские науки. 